\title{
ECONOMIC GROWTH, INFLATION, AND CAPITAL MARKET PERFORMANCE: IS THERE A LINK IN JORDAN?
}

\section{DOI: 10.17261/Pressacademia.2021.1373}

JEFA- V.8-ISS.1-2021(1)-p.1-7

\section{Mohammad Khataybeh ${ }^{1}$, Ghassan Omet ${ }^{2}$}

${ }^{1}$ University of Jordan, Department of Finance, Amman, Jordan.

khataybeh@ju.edu.jo, ORCID: 0000-0003-3599-903X

${ }^{2}$ University of Jordan, Department of Finance, Amman, Jordan. gomet@ju.edu.jo, ORCID: 0000-0002-8988-1387

\begin{tabular}{l}
\hline Date Received: December 15, $2020 \quad$ Date Accepted: February 27, 2021 \\
\hline To cite this document \\
Khataybeh, M., Omet, G.,(2021). Economic growth, inflation and capital market performance: is there a link in Jordan? Journal of \\
Economics, Finance and Accounting (JEFA), V.8(1), p.1-7. \\
Permanent link to this document: $h$ http://doi.org/10.17261/Pressacademia.2021.1373 \\
Copyright: Published by PressAcademia and limited licensed re-use rights only.
\end{tabular}

\section{ABSTRACT}

Purpose - The relationship between some macroeconomic variables and stock market returns still attracts the attention of researchers. Indeed, this interest lies in the fact the stock development enhances real economic growth. Within this context, the objective of this paper is to examine the Jordanian capital market (Amman Stock Exchange / ASE) in terms of the nexus between macroeconomic variables and the stock price index.

Methodology - To examine the relationship between real Gross Domestic Product (GDP) and consumer price index (CPI) and the ASE's market index, this paper covers the period 1980 - 2019, and uses time series techniques including stationarity test, lag length selection criteria, co-integration, Vector Error Correction Model (VECM), and some stability tests.

Findings - In contrast to most of the published literature, the impact of real GDP on the ASE's market index and on its market capitalization is negative and significant. In addition, while the impact of consumer price index on the market index is not significant, its impact of market capitalization is negative and significant.

Conclusion - Based on the estimated results, we argue that the ASE's performance does not reflect the performance of the national economy. On the contrary, the relationship is negative. In addition, we argue that the ASE's market index does not hedge investors against inflation. These results indicate that the ASE's market index should not be used as a proxy measure of the performance of the national economy.

Keywords: Amman Securities Exchange, macroeconomic variables, market index, co-integration, Fisher. JEL Codes: G10, G12, G14

\section{INTRODUCTION}

The importance of stock markets (and banks) in the process of economic growth and development of nations has always been an issue that interests researchers, as well as international organizations, such as the World Bank and the International Monetary Fund (IMF).

Financial systems encourage savings, facilitate trading activity in the issued financial securities, allow investors to diversify their investment portfolios, improve the allocation process of scarce capital resources, and monitor the performance of company managers (Levine, 1997). Given these important services, both the World Bank and the IMF maintain their own databases that measure financial development across the globe. The World Bank's framework relies on four proxy dimensions that characterize a well-functioning financial system, and these are depth, access, efficiency, and stability. The IMF's framework on the other hand, relies on depth, access, and efficiency dimensions.

To measure their dimensions of financial development, the IMF and the World Bank use a wide set of almost similar variables. For example, they both the depth of financial institutions in terms of market capitalization to GDP ratio. 
The market capitalization to GDP ratio in general, and what affects market indices (and market capitalization) in particular, has been a challenging issue to the economic and finance research community. Indeed, publicly traded companies take their stock prices seriously because they reflect their overall financial health. In addition, if a company decides to raise capital, the higher its prevailing stock price, the less shares its needs to issue. Finally, when a company's stock price rises, the likelihood / probability of a takeover decreases.

The seminal paper by Fisher (1930) has led to the publication of many empirical papers that examine the relationship between stock returns and some macroeconomic variables. According to Fisher (1930), in efficient markets, the nominal returns on financial securities consist of expected and unexpected inflation rate, and risk premium. In other words, Fisher predicts a positive relationship between stock returns and expected inflation. Following this, Bodie (1976), Jaffe and Mandelker (1976), Fama and Schwert (1977), and Fama (1981), have all reported a negative relationship between expected inflation, unexpected inflation, and changes in the expected inflation and nominal and real stock returns. These early papers are still relevant and attract the research community to examine the nexus between macroeconomic variables and stock prices.

This paper examines the relationship between real GDP and inflation rate and the performance of the ASE in terms of its weighted market index and market capitalization. In section 2, a brief review of the literature is presented. In sections 3 and 4, we outline the data and methodology, and present and discuss the results. Finally, section 5 summarizes and concludes the paper.

\section{THE MACROECONOMY AND STOCK MARKET PERFORMANCE: LITERATURE REVIEW}

As implied in the introduction, the pioneering idea about the relationship between financial assets' returns and inflation is due to the work of Fisher (1930). This effort has resulted in the publication of a number of early papers in this area. These include, for example, Lintner (1975), Bodie (1976), Jaffe and Mandelker (1976), Fama and Schwert (1977), and Fama (1981). Following these publications, numerous other papers have emerged. These include Fama (1990), Chen et al. (1986), Fama and French (1989), Chen (1991), Thornton (1993), Kaneko and Lee (1995), Abdalla and Murinde (1997).

Fama and Schwert (1977) estimate the extent to which assets are a hedge / protection against the expected and the unexpected components of inflation rates in the USA during the period $1953-1971$. The analyzed assets are common stocks' (New York Stock Exchange (NYSE) equally-weighted portfolio, value-weighted portfolio, US treasury bills, long-term US government bonds, Home Purchase Price Index (HPPI), and labor income. The empirical results indicate that while treasury bills and bonds are a hedge against expected inflation, the HPPI is a hedge against both expected and unexpected inflation. Labor income does not reflect any relationship with inflation (expected and unexpected). Finally, common stock returns are negatively related to inflation. These findings are also documented by Lintner (1975), Jaffe and Mandelker (1976), and Nelson (1976).

More recent papers include Phylaktis \& Ravazzolo (2005), Humpe and Macmillan (2009), Eita (2012), Ibrahim \& Agbaje (2013), Tripathi \& Kumar (2014) , Hunjra, Chani, Shahzad \& Khan (2014), Boonyanam (2014), Barakat et al. (2016), Okoro (2017), Badullahewage (2018), Al-Kandari and Abul (2019), Khataybeh et al.( 2019), Radha and Gopinathan (2019), and Olokoyo et al. (2020).

Humpe and Macmillan (2009) examine the impact of four macroeconomic variables (industrial production index, consumer price index, money supply, and long-term interest rates) on stock prices in the USA and Japan. The results indicate some conflicting conclusions. For example, while the USA's analysis finds one co-integrating vector, the Japanese findings find two co-integrating vectors. In the USA, stock prices are positively related to the industrial production index, and negatively related to the consumer price index and long-term interest rate. The relationship between stock prices and the money supply is not significant. For the Japanese findings, on the other hand, stock prices are positively related to the industrial production index, and negatively related to money supply. For the second co-integrating vector, the estimated results indicate that the industrial production index is negatively affected by the consumer price index and long-term interest rate. These contrasting findings, it is argued, are due to the recession that hit the Japanese economy during the 1990s.

Finally, Olokoyo et al. (2020) use time series econometric techniques to examine the impact of various macro-economic variables on the market capitalization of the Nigerian stock exchange. The macro-economic variables include interest rate, exchange rate, GDP, inflation, foreign capital inflows, and trade openness (exports and imports to GDP ratio). Based on the Johansen co-integration test and vector error correction model (VECM), Olokoyo et al. (2020) document a negative relationship between interest rate, inflation and trade and market capitalization, and a positive relationship between GDP growth rate and market capitalization. 


\section{THE DATA AND METHODOLOGY}

This paper examines the impact of real GDP and inflation on the stock market performance in Jordan during the period 1980-2019. To carry out this exercise, we specify models 1 and 2.

$\mathrm{SMI}_{\mathrm{t}}=\lambda+\beta \mathrm{GDP}_{\mathrm{t}}+\psi \mathrm{CPI}_{\mathrm{t}}+\varepsilon_{\mathrm{t}}$

$M C_{t}=\lambda+\beta G D P_{t}+\psi C P I_{t}+\varepsilon_{t}$

where, SMI is the stock market index, MC is the market capitalization of the stock exchange, GDP is real GDP, CPI is the consumer price index. All four variables are in their logarithmic forms. The expected signs of the parameters are $\lambda>0, \beta>0$, $\psi>0$. The error term $(\varepsilon)$ is assumed to be is independent and identically in its distribution. Finally, the subscript (t) stands for the period used in the analysis (1980-2019).

The fact that the paper uses time series data and covers the period $1980-2019$ (40 observations), we follow five steps.

First, we examine the stationarity of the data using the Augmented Dickey-Fuller (ADF) test.

Second, we use the Schwarz information criterion (SC) to select the optimum lag number through an unrestricted vector autoregressive model (VAR) model.

Third, we apply the Johansen co-integration test to detect the long run relationship among the variables. This cointegration is tested using the maximum eigenvalue $\left(\lambda_{\max }\right)$ and the trace test $\left(\lambda_{\text {trace }}\right)$.

$\lambda_{\max }=-\mathrm{T} \log \left(1-\lambda_{r+1}\right)$

where, the null is $r=g$ co-integrating vectors with $(g=0,1,2,3, \ldots)$ against the alternative $(r \leq g+1)$.

$\lambda_{\text {trace }}=-\mathrm{T} \sum_{\mathrm{i}=\mathrm{r}+1}^{\mathrm{k}} \log \left(1-\lambda_{\mathrm{i}}\right)$

where, the null is $r=\mathrm{g}$ against the general specification $r \leq 1$.

Fourth, the restricted vector auto-regression (Vector Error Correction Model / VECM) model is then estimated to examine the short run effect of the macro-economic variables (GDP and inflation) on the performance of the ASE.

We then estimate a vector error-correction (VEC) model to examine the long-run relationship between the set of variables.

$\Delta \mathrm{SMI}_{\mathrm{t}}=\alpha+\lambda e_{\mathrm{t}-1}+\sum_{i=1}^{n} b \mathrm{i} \Delta \mathrm{GDP}_{\mathrm{t}-\mathrm{i}}+\sum_{i=1}^{m} c \mathrm{i} \Delta \mathrm{CPI}_{\mathrm{t}-\mathrm{i}}+\varepsilon_{\mathrm{t}}$

$\Delta \mathrm{MC}_{\mathrm{t}}=\alpha+\lambda e_{\mathrm{t}-1}+\sum_{i=1}^{n} b \mathrm{i} \Delta \mathrm{GDP}_{\mathrm{t}-\mathrm{i}}+\sum_{i=1}^{m} c \mathrm{i} \Delta \mathrm{CPI}_{\mathrm{t}-\mathrm{i}}+\varepsilon_{\mathrm{t}}$

Finally, we estimate Breusch-Godfrey Serial Correlation LM test, and CUSUM test for the stability of the residuals.

\section{THE EMPIRICAL RESULTS}

Before we present the empirical estimations, it is useful to outline a number of observations about the ASE. First, the ASE was established in 1978. As expected, in 1978, the ASE was a small market in terms of, for example, number of listed companies (66), market capitalization to GDP ratio (36.0 percent), and in terms of its trading volume to GDP ratio / turnover ratio (2.0 percent). Second, around the year 2008, the market hit record levels in capitalization, number of listed companies, and turnover ratio. However, since 2008 - 2010, the market has experienced falls in all of these measures. In 2020, the market had 179 listed companies (down from 277 in 2010), 41.5 percent capitalization to GDP ratio (down from 162.9 percent in 2010), and 8.1 percent turnover ratio (down from 80.0 percent in 2008).

Table 1: The ASE: Basic Information

\begin{tabular}{|c|c|c|c|}
\hline Year & Number of Listed Firms & Capitalization to GDP Ratio & Turnover Ratio \\
\hline 1978 & 66 & $36.0 \%$ & $2.0 \%$ \\
\hline 1998 & 150 & $74.1 \%$ & $11.2 \%$ \\
\hline 2008 & 262 & $298.8 \%$ & $80.0 \%$ \\
\hline 2010 & 277 & $162.9 \%$ & $30.6 \%$ \\
\hline 2012 & 243 & $116.5 \%$ & $10.3 \%$ \\
\hline 2018 & 195 & $56.7 \%$ & $14.4 \%$ \\
\hline 2019 & 191 & $49.7 \%$ & $10.6 \%$ \\
\hline 2020 & 179 & $41.5 \%$ & $8.1 \%$ \\
\hline
\end{tabular}


In Table 2, we report of the ADF test results. It is clear that all four variables are not stationary at their level forms and once first-differenced, they become stationary.

Based on these results, we can move to the next step in the analysis and apply the Johansen co-integration test to detect the long-term co-integrating relationship among our set of variables. However, before this step, we need to determine the lag structure for the estimation of models 1 and 2 .

Table 2: Unit Root Test - Augmented Dickey-Fuller Test

\begin{tabular}{|l|c|c|c|c|c|c|}
\hline & \multicolumn{3}{|c|}{ Level } & \multicolumn{3}{c|}{ First-Difference } \\
\hline & None & Constant & $\begin{array}{c}\text { Constant \& } \\
\text { Trend }\end{array}$ & None & Constant & $\begin{array}{c}\text { Constant \& } \\
\text { Trend }\end{array}$ \\
\hline $\begin{array}{l}\text { Overall Stock Market } \\
\text { Index }\end{array}$ & 0.974 & -1.306 & -1.469 & $-5.810^{*}$ & $-5.797^{*}$ & $-5.703^{*}$ \\
\hline Market Capitalization & 2.397 & -1.792 & -0.800 & $-2.862^{*}$ & $-4.922^{*}$ & $-4.941^{*}$ \\
\hline Real GDP & 3.345 & 0.263 & -2.154 & $-3.772^{*}$ & $-5.382^{*}$ & $-5.341^{*}$ \\
\hline Consumer Price Index & 2.105 & -1.470 & -2.011 & $-1.397^{*}$ & $-3.699^{*}$ & $-3.858^{*}$ \\
\hline
\end{tabular}

In Tables 3 and 4, we present the results of lag structure determination during the period 1980-2019. On average, the reported results indicate that the optimum lag for both estimations is 2 . This lag is used in estimating the Johansen cointegration test.

Table 3: Endogenous Variables - Overall Market Index, Real GDP, and Consumer Price Index

\begin{tabular}{|c|c|c|c|c|c|c|}
\hline Lag & LogL & LR & FPE & AIC & SC & HQ \\
\hline 0 & -18.64213 & NA & 0.000647 & 1.169845 & 1.300460 & 1.215893 \\
\hline 1 & 159.1503 & 317.1432 & $7.07 \mathrm{e}-08$ & -7.954070 & $-7.431610^{*}$ & -7.769878 \\
\hline 2 & 173.0605 & $22.55710^{*}$ & $5.48 \mathrm{e}-08^{*}$ & $-8.219487^{*}$ & -7.305182 & $-7.897152^{*}$ \\
\hline 3 & 178.5275 & 7.978796 & $6.82 \mathrm{e}-08$ & -8.028511 & -6.722362 & -7.568032 \\
\hline
\end{tabular}

Table 4: Endogenous Variables - Market Capitalization, Real GDP, and Consumer Price Index

\begin{tabular}{|c|c|c|c|c|c|c|}
\hline Lag & LogL & LR & FPE & AIC & SC & HQ \\
\hline 0 & -24.81329 & NA & 0.000903 & 1.503421 & 1.634036 & 1.549469 \\
\hline 1 & 160.0159 & 329.6953 & $6.74 \mathrm{e}-08$ & -8.000858 & $-7.478398^{*}$ & -7.816667 \\
\hline 2 & 175.1613 & $24.56015^{*}$ & $4.89 \mathrm{e}-08^{*}$ & $-8.333043^{*}$ & -7.418739 & $-8.010708^{*}$ \\
\hline 3 & 182.1923 & 10.26151 & $5.59 \mathrm{e}-08$ & -8.226613 & -6.920463 & -7.766134 \\
\hline
\end{tabular}

In Table 5-8, we report the Johansen co-integration test results. The reported trace and maximum eigenvalue statistics indicate that there is at least one co-integrating relationship at the 5 percent significance level exits in all four estimations. In other words, there is a long-run relationship between the stock market index, GDP and inflation. There is also a longrun relationship between market capitalization, GDP, and inflation. These conclusions indicate that the estimation of a Vector Error Correction Model (VEC) is the second step.

Table 5: Johansen Multivariate Co-Integration Test

\begin{tabular}{|l|c|c|c|c|}
\hline $\begin{array}{l}\text { Hypothesized No. of } \\
\text { CE(s) }\end{array}$ & Eigen Value & Trace Statistic & $\begin{array}{c}\text { 5 Percent Critical } \\
\text { Value }\end{array}$ & P-Value \\
\hline None ${ }^{*}$ & 0.446054 & 30.59660 & 29.79707 & 0.0404 \\
\hline At most 1 & 0.188780 & 8.741120 & 15.49471 & 0.3899 \\
\hline At most 2 & 0.026668 & 1.000108 & 3.841466 & 0.3173 \\
\hline
\end{tabular}

Overall Market Index, Real GDP, and Consumer Price Index.

Table 6: Johansen Multivariate Co-Integration Test

\begin{tabular}{|l|c|c|c|c|}
\hline $\begin{array}{l}\text { Hypothesized No. of } \\
\text { CE(s) }\end{array}$ & Eigenvalue & Max-Eigen Statistic & $\begin{array}{c}\text { 5 percent Critical } \\
\text { Value }\end{array}$ & Prob. $^{* *}$ \\
\hline None & & 21.85548 & 21.13162 & 0.0395 \\
\hline At most 1 & 0.446054 & 7.741012 & 14.26460 & 0.4056 \\
\hline At most 2 & 0.188780 & 1.000108 & 3.841466 & 0.3173 \\
\hline
\end{tabular}


Overall Market Index, Real GDP, and Consumer Price Index.

Table 7: Johansen Multivariate Co-Integration Test

\begin{tabular}{|l|c|c|c|c|}
\hline $\begin{array}{l}\text { Hypothesized No. of } \\
\text { CE(s) }\end{array}$ & Eigen Value & Trace Statistic & $\begin{array}{c}\text { 5 Percent Critical } \\
\text { Value }\end{array}$ & P-Value \\
\hline None & & 33.71083 & 29.79707 & 0.0168 \\
\hline At most 1 & 0.484639 & 9.183977 & 15.49471 & 0.3487 \\
\hline At most 2 & 0.190305 & 1.373346 & 3.841466 & 0.2412 \\
\hline
\end{tabular}

Market Capitalization, Real GDP, and Consumer Price Index

TABLE 8: Johansen Multivariate Co-Integration Test

\begin{tabular}{|l|c|c|c|c|}
\hline $\begin{array}{l}\text { Hypothesized No. of } \\
\text { CE(s) }\end{array}$ & Eigen Value & Max-Eigen Statistic & $\begin{array}{c}\text { 5 Percent Critical } \\
\text { Value }\end{array}$ & P-Value \\
\hline None ${ }^{*}$ & 0.484639 & 24.52686 & 21.13162 & 0.0160 \\
\hline At most 1 & 0.190305 & 7.810632 & 14.26460 & 0.3983 \\
\hline At most 2 & 0.036437 & 1.373346 & 3.841466 & 0.2412 \\
\hline
\end{tabular}

Market Capitalization, Real GDP, and Consumer Price Index

In Tables 9, we report the results of the co-integrating equations. The results indicate that real GDP has a negative and significant impact on both the ASE's market index and its market capitalization. However, the consumer price index affects (negatively) the ASE's market capitalization only. In addition, the VECM results (Table 10) indicate that the error correction terms is negative and significant in both estimations. These terms indicate that there is a long-run equilibrium relationship between real GDP, inflation, and stock market index, and between real GDP, inflation, and market capitalization.

Table 9: Co-Integrating Regressions

\begin{tabular}{|l|c|c|l|c|c|}
\hline \multicolumn{2}{|c|}{ Dependent Variable - Stock Market Index } & \multicolumn{3}{c|}{ Dependent Variable - Market Capitalization } \\
\hline Variable & Coefficient & t-Statistic & Variable & Coefficient & t-Statistic \\
\hline C & +29.682 & & C & +20.669 & \\
\hline GDP & -1.620 & $6.354^{*}$ & GDP & -1.707 & $-5.337^{*}$ \\
\hline CPI & +0.140 & 0.576 & CPI & -0.787 & $-2.626^{*}$ \\
\hline * Significant at the 99 percent level. \\
\hline
\end{tabular}

Table 10: VECM Estimation Results

\begin{tabular}{|c|c|c|c|}
\hline$\Delta \mathrm{SMI}_{\mathrm{t}}$ & t-statistic & $\Delta M C_{t}$ & t-statistic \\
\hline$-0.261 E C T_{t-1}$ & -1.411 & $-0.1994 \mathrm{ECT}_{\mathrm{t}-1}$ & -1.543 \\
\hline$+0.226 \Delta \mathrm{SMI}_{\mathrm{t}-1}$ & 1.245 & $+0.357 \Delta \mathrm{SMI}_{\mathrm{t}-1}$ & 2.058 \\
\hline$+0.311 \Delta \mathrm{SMI}_{\mathrm{t}-2}$ & 1.660 & $+0.283 \Delta \mathrm{SMI}_{\mathrm{t}-2}$ & 1.510 \\
\hline$+2.061 \Delta \mathrm{GDP}_{\mathrm{t}-1}$ & 1.474 & $+2.283 \Delta G P_{t-1}$ & 1.731 \\
\hline$-1.510 \Delta \mathrm{GDP}_{\mathrm{t}-2}$ & -1.227 & $-1.355 \Delta \mathrm{GDP}_{\mathrm{t}-2}$ & -1.282 \\
\hline$+0.196 \Delta \mathrm{CPI}_{\mathrm{t}-1}$ & 0.158 & $+0.309 \Delta \mathrm{CPI}_{\mathrm{t}-1}$ & 0.267 \\
\hline$-0.022 \Delta C P I_{t-2}$ & -0.022 & $-0.157 \Delta C P I_{t-2}$ & -0.179 \\
\hline-0.018 & -0.138 & -0.017 & -0.172 \\
\hline $\mathrm{R}^{2}$ & 0.301 & $\mathrm{R}^{2}$ & 0.340 \\
\hline Adjusted $\mathrm{R}^{2}$ & 0.132 & Adjusted $\mathrm{R}^{2}$ & 0.181 \\
\hline
\end{tabular}

To analyze the residuals in terms of their serial correlation behavior, we conduct the LM test as a residual diagnostic test. The results are reported in Tables 11 and 12. Clearly, the results indicate the absence of serial correlation in the error terms.

Table 11: Breusch-Godfrey Serial Correlation LM Test (MARKET INDEX, GDP \& INFLATION)

\begin{tabular}{|l|c|c|c|}
\hline F-statistic & $\mathbf{0 . 4 4 4 3 5 7}$ & Prob. F(2,27) & $\mathbf{0 . 6 4 5 8}$ \\
\hline Obs*R-squared & 1.179058 & Prob. Chi-Square(2) & 0.5546 \\
\hline
\end{tabular}


Table 12: Breusch-Godfrey Serial Correlation LM Test (MARKET CAPITALIZATION, GDP, \& INFLATION)

\begin{tabular}{|l|c|c|c|}
\hline F-statistic & $\mathbf{0 . 3 8 9 8 3 5}$ & Prob. F(2,27) & $\mathbf{0 . 6 8 0 9}$ \\
\hline Obs*R-squared & 1.038451 & Prob. Chi-Square(2) & 0.5950 \\
\hline
\end{tabular}

Finally, we conduct the CUSUM test for the parameters' structural stability. The results are shown in Graphs 1 and 2 . In both cases, the CUSUM plots for the estimated ECMs show no movement outside the $5 \%$ critical lines. Therefore, the estimated ECMs are stable.
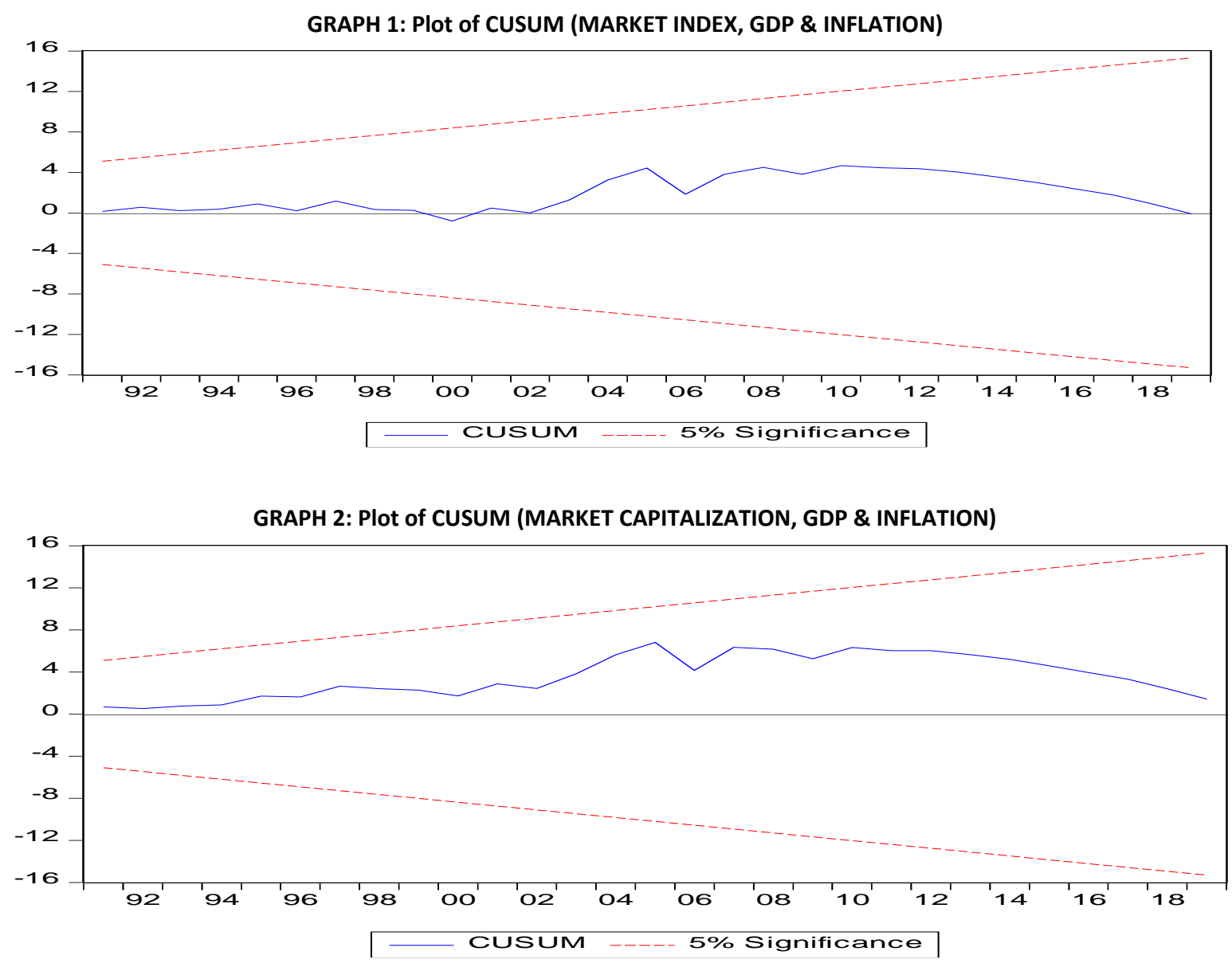

\section{SUMMARY AND CONCLUSIONS}

The purpose of this paper is to investigate the impact of real GDP and inflation on the Jordanian stock exchange's market index and its market capitalization. The fact that the annual data covers the period $1980-2019$, we use time series techniques including the Augmented Dickey Fuller test, lag section criterion, Johansen co-integration test, and vector error-correction model (VECM).

The empirical findings confirm the existence of a long-run relationship between stock market index, real GDP, and consumer price index, and between market capitalization, real GDP, and consumer price index. Our findings do not support the hypothesis that economic growth has a positive impact on the performance of the stock market in terms of its overall market index or market capitalization. On the contrary, the impact of real GDP on these performance measures is negative. In addition, while the consumer price index has no impact on the overall market index, its impact on market capitalization is negative and significant. In other words, stock market prices in the ASE do not hedge investors against inflation rate.

Based on the reported results, three main conclusions are worth raising. First, it is surprising to find that real GDP has a negative impact on the overall market index and on market capitalization. After all, the ASE lists the largest companies in the country in terms of their total assets, number of employees, and net income. Moreover, all Jordanian banks are listed 
on the market. The performance of the economy should be reflected in the market's index and its capitalization. However, the fact that this is not the case, one can argue that the reason behind the negative impact is lack of efficiency in the pricing of the listed firms themselves.

\section{REFERENCES}

Abdalla, I. \& Murinde, V. (1997). Exchange rate and stock price interactions in emerging financial markets: Evidence on India, Korea, Pakistan, and Philippines. Applied Financial Economics, 7, 25-35.

Ben Naceur, S. \& Zhang, R (2016). Financial development, inequality and poverty: Some international evidence. IMF Working Paper No. $16 / 32$.

Bodie, Z. 1976. Common stocks as a hedge against inflation. The Journal of Finance, 31, 459-70.

Boonyanam, N. (2014). Relationship of stock price and monetary variables of Asian small open emerging economy: Evidence from Thailand. International Journal of Financial Research, 5, 52-63.

Chen, Nai-Fu (1991). Financial investment opportunities and the macroeconomy. Journal of Finance, 46, 529-554.

Chen, N., Roll, R \& Ross, S. (1986). Economic forces and the stock Market. Journal of Business, 59, 383-403.

Eita, J. (2012). Modelling macroeconomic determinants of stock market prices: Evidence from Namibia. Journal of Applied Business Research, 4, 871-884.

Fama, E. \& Schwert, O. (1977). Asset returns and inflation. Journal of Financial Economic, 5, $120-132$.

Fama, E. (1981). Stock returns, real activity, inflation and money. The American Economic Review, 71, 45-565.

Fama, E. F. (1990). Stock returns, expected returns and real activity. Journal of Finance, 45, 1089-1108.

Fama E. \& French, F. (1989). Business conditions and expected prices on stocks and bonds. Journal of Financial Economics, $25,23-49$.

Fisher, I. (1930). The Theory of Interest, The Macmillan Company.

Humpe, A. \& Macmillan, P. (2009). Can macroeconomic variables explain long-term stock market movements? A comparison of the US and Japan. Applied Financial Economics, 19, 111-19.

Hunjra, A., Chani, M., Shahzad, M., \& Khan, F. (2014). The impact of macroeconomic variables on stock prices in Pakistan. International Journal of Economics and Empirical Research, 2, 13-21.

Ibrahim, T. \& Agbaje, M (2013). The relationship between stock return and inflation in Nigeria. European Scientific Journal, 9, $146-157$.

Jaffe, J., \& Mandelker, G. (1976). The "Fisher effect" for risky assets: an empirical investigation. Journal of Finance, 31, 447-58.

Kaneko T, \& Lee, B. (1995). Relative importance of the economic factors in the U.S. and Japanese stock markets. Journal of the Japanese and International Economies, 9, 209-307.

Khataybeh, Mohammad A.;Abdulaziz, Mohamad;Marashdeh, Zyad (2019). Cross-Sectional Relationship Between Beta and Realized Returns in Emerging Markets. Applied Economics Quarterly, 65, (2),115-137.

Levine, R. (1997). Financial development and economic growth: Views and agenda. Journal of Economic Literature, XXXV, 688-726.

Lintner, J. (1975), Inflation and security returns. The Journal of Finance, 30, 259-280.

Nelson, C.R. (1976). Inflation and rates of return on common stocks. The Journal of Finance, 31, 471-483.

Olokoyo, F., Ibhagui, O. \& Babajide, A. (2020). Macroeconomic indicators and capital market performance: Are the links sustainable? Cogent Business \& Management, 7, 1-17.

Phylaktis, K. \& Ravazzolo, F. (2005). Stock prices and exchange rate dynamics. Journal of International Money and Finance, $24,1031-1053$.

Thornton J (1993). Money, output and stock prices in the UK. Applied Financial Economics, 3, 335-338.

Tripathi, V. \& Kumar, A. (2014). Relationship between inflation and stock returns evidence from Brics markets. International Journal of Accounting and Finance Reporting, 4, 647-658. 